\title{
MANAJEMEN PEMBELAJARAN MATEMATIKA DALAM MENINGKATKAN MINAT BELAJAR SISWA SD UNGGULAN MUSLIMAT NU KABUPATEN KUDUS
}

\author{
Ummi Hanik Nashihah \\ IAIN Kudus, Indonesia \\ hannynazhiha26@gmail.com
}

\begin{abstract}
Abstrak
Penelitian ini bertujuan memberikan gambaran tentang minat belajar siswa dan manajemen pembelajaran matematika di SD Unggulan Muslimat NU Kabupatan Kudus. Hasil penelitian menunjukkan: 1) Siswa-siswi di SD Unggulan Muslimat NU Kudus memiliki minat belajar pada mata pelajaran matematika yang beragam, diperlukan peran guru dalam membangkitkan sikap positif dan merancang pembelajaran matematika dibutuhkan agar perlahan-lahan dapat menumbuhkan minat belajar siswa terhadap matematika; 2) Untuk meningkatkan minat belajar siswa guru lebih mengoptimalkan dalam merencanakan komponen-komponen yang ada dalam RPP yaitu tujuan pembelajaran, materi pembelajaran, metode pembelajaran, media pembelajaran, sumber belajar, dan penilaian pembelajaran; 3) Pengorganisasian yang dilakukan dalam menunjang kegiatan belajar matematika diantaranya yaitu pengorganisasian kurikulum, sarana dan prasarana, guru, serta pengorganisasian siswa; 4) Pelaksanaan pembelajaran matematika dilakukan dalam tiga kegiatan yaitu kegiatan pendahuluan, inti, dan penutup dengan tetap menjaga perhatian siswa agar fokus dalam pembelajaran; 5) Evaluasi pembelajaran dilaksanakan dengan jenis evaluasi formatif dan sumatif.
\end{abstract}

Kata Kunci: Manajemen Pembelajaran; Matematika; Minat Belajar.

\begin{abstract}
This study aims to provide an overview of students interest in learning and management of mathematics learning in SD Unggulan Muslimat NU Kudus. The results showed: 1) Students in SD Unggulan Muslimat NU Kudus have an interest in learning in a variety of mathematics subjects, required the role of the teacher in arousing positive attitudes and designing mathematics learning is needed so that slowly it can foster students' interest in learning towards mathematics; 2) To increase students' interest in learning the teacher optimizes in planning the components contained in the lesson plan namely learning objectives, learning materials, learning methods, learning media, learning resources, and learning assessment; 3) Organizing carried out in supporting mathematics learning activities including organizing the curriculum, facilities and infrastructure, teachers, and organizing students; 4) The implementation of mathematics learning is carried out in three activities namely preliminary, core, and closing activities while maintaining student attention so that the focus is in learning; 5) Evaluation of learning is carried out with formative and summative evaluation types.
\end{abstract}

Keywords: Learning Management, Mathemathic, Interest in Learning. 


\section{Ummi Hanik Nashihah}

\section{A. Pendahuluan}

Matematika adalah ilmu hitung yang bermanfaat untuk kehidupan. Matematika juga berfungsi sebagai dasar logika dan ide-ide abstrak untuk meningkatkan kemampuan argumentasi serta berpikir, memberikan kontribusi dalam pemecahan suatu masalah (Susanto, 2015:185). Cabang ilmu matematika memberikan sumbangan yang positif untuk kemajuan ilmu pengetahuan dan teknologi (Gradini, 2017:2).

Matematika terdiri dari elemen-elemen yang tidak didefinisikan, definisi, aksioma, dan dalil yang dapat dibuktikan kebenarannya (Ruseffendi, 1989:41). Secara filosofi, matematika merupakan ilmu yang bersumber dari Al-Qur'an. Bagian-bagian yang dipelajari dalam matematika didasari dari ayat-ayat Al-Qur'an. Misalnya tentang bilangan, banyak ayat Al-Qur'an yang menuansai materi tersebut. Seperti Surat Al-An'am ayat 96 yang artinya "Dia menyingsingkan pagi dan menjadikan malam untuk beristirahat, dan (menjadikan) matahari dan bulan untuk perhitungan. Itulah ketentuan Allah yang Maha Perkasa lagi Maha mengetahui”. Dan Al-Isra' ayat 12 “dan Kami jadikan malam dan siang sebagai dua tanda, lalu Kami hapuskan tanda malam dan Kami jadikan tanda siang itu terang, agar kamu mencari kurnia dari Tuhanmu, dan supaya kamu mengetahui bilangan tahun-tahun dan perhitungan. dan segala sesuatu telah Kami terangkan dengan jelas." yang menegaskan perputaran bulan dan matahari sebagai alat bantu manusia melakukan perhitungan.

Pembelajaran matematika menurut Suyitno dalam bukunya Rora Rizki Wandini dkk adalah suatu kegiatan mengajarkan matematika yang dilakukan guru matematika kepada siswanya, sebagai upaya untuk menciptakan suasana dan interaksi antara guru dengan siswa atau antara siswa dan siwa lainnya secara, serta memberikan pelayanan terhadap kemampuan, miat, potensi, bakat dan kebutuhan siswa mengenai matematika secara optimal (Wandini, 2019: 5-6). Mata pelajaran matematika menjadi bagian dari syarat untuk meneruskan pendidikan ke jenjang selanjutnya. Artinya, penguasaan ilmu matematika sangat penting dimiliki setiap orang

- Sayangnya, sejak lama matematika seakan menjadi mata pelajaran paling dihindari oleh sebagian besar siswa. Kenyataan ini bisa dilihat pada kebanyakan sekolah di mana pun, antusiasme siswa langsung turun seketika pada saat pelajaran matematika. Siswa seringkali berasumsi bahwa matematika adalah pelajaran yang sulit dan tidak menyenangkan (Lasmanawati, 2014).

Minimnya minat siswa terhadap matematika masih menjadi persoalan serius dalam proses pembelajaran. Padahal, minat menjadi faktor yang sangat penting dalam proses 


\section{Ummi Hanik Nashihah}

belajar siswa. Minat menjadi kekuatan yang dapat menggerakkan seseorang untuk memfokuskan perhatian terhadap seseorang, benda, ataupun kegiatan tertentu. Dengan begitu minat menjadi unsur yang memunculkan motivasi sehingga siswa dapat berkonsentrasi kepada suatu benda atau kegiatan tertentu. Menurut Uzer Usman dalam bukunya Susanto minat belajar adalah faktor penentu tingkat keaktifan siswa. Dengan demikian, dapat disimpulkan bahwa minat menjadi faktor yang paling berpengaruh terhadap kesuksesan belajar siswa (Susanto, 2015: 66-67).

Minat mempunyai arti suatu kecenderungan seseorang untuk memusatkan perhatian dan bertindak dengan perasaan senang terhadap orang, situasi, atau kegiatan yang menjadi fokus dari minat tersebut. Pada pembahasan tersebut terdapat suatu pengertian bahwa di dalam minat ada pemfokusan perhatian subyek, ada usaha untuk mengetahui, menguasai, mendekati, memiliki, obyek dengan perasaan senang (Shaleh, 2004: 263).

Menurut Susanto mengutip Gagne, persoalan minat belajar ini dibagi menjadi dua jenis. Pertama, yaitu minat yang tumbuh dari dalam diri seorang siswa tanpa pengaruhi dari luar atau minat spontan. Kedua, minat yang terpola yaitu minat yang tumbuh sebab tepengaruh dari kegiatan yang terencana dan terpola. Seperti halnya peminatan terhadap mata pelajaran tertentu tidak lepas dari pengaruh sistem pembelajaran atau manajemen pembelajaran suatu lembaga pendidikan (Susanto, 2015:60-61).

Manajemen adalah suatu proses pemanfaatan seluruh sumber daya yang ada dalam mencapai suatu tujuan (Bafadal, 2004: 1). Manajemen merupakan suatu proses perencanaan, pengorganisasian, pelaksanan, dan pengendalian organisasi beserta seluruh aspek di dalamnya agar tujuan suatu lembaga dapat tercapai secara efektif dan juga efisien (Sutikno, 2012:4). Jadi, manajemen merupakan suatu proses pendayagunaan mulai dari perencanaan, pengorganisasian, pelaksanaan, dan juga pengawasan semua sumber daya dalam rangka mewujudkan tujuan secara optimal.

Pengertian pembelajaran menurt Mulyasa adalah hubungan timbal balik antara peserta didik dengan lingkungan sehingga menyebabkan terjadinya pergeseran perilaku ke arah yang lebih baik. Pembelajaran merupakan proses yang diselenggarakan pendidik untuk membelajarakan siswa dalam suatu kegiatan belajar dengan tujuan memperoleh, dan memproses pengetahuan, siakap, dan keterampilan (Mulyasa, 2010: 100).

Pembelajaran adalah suatu sistem yang terdiri atas beberapa komponen yang mempunyai kaitan satu sama lain. Kompenen tersebut meliputi: guru, siswa, materi, tujuan, metode, media dan evaluasi. Pada hakikatnya, pembelajaran merupakan suatu 


\section{Ummi Hanik Nashihah}

proses timbal balik antara pendidik dan peserta didiknya, baik secara langsung maupun tidak langsung misalnya kegiatan tatap muka atau kegiatan yang menggunakan media pembelajaran (Rusman, 2011:1).

Manajemen pembelajaran adalah seluruh upaya pengaturan kegiatan pembelajaran dalam upaya menciptakan kegiatan pembelajaran yang efektif dan efisisen (Bafadal, 2004: 11). Manajemen pembelajaran juga dapat diartikan sebagai upaya guru dalam merencankan, melaksanakan kegiatan belajar mengajar dan mengevaluasi hasil pembelajaran. Seorang guru hendaknya menguasai keterampilan dalam mengelola pembelajaran yang meliputi tiga tahap kegiatan yaitu: membuat perncanaan pembelajaran, melaksanakan kegiatan pembelajaran, dan melakukan evaluasi pembalajaran (Puspita, 2008: 23).

Manajemen pembelajaran memilik peran yang penting dalam pendidikan khususnya pada kegiatan pembelajaran di sekolah antara guru dan juga siswanya, dengan adanya manajemen pembelajaran seorang guru dapat mengetahui tata cara pengelolaan yang berkaitan dengan kegiatan pembelajaran secara efektif dan efisien, sehingga guru dapat menerapkan pengelolaan dengan baik dan dapat tercapai tujuan pembelajaran yang diharapkan.

Adanya manajemen pembelajaran yang seperti itu tentu akan membuat proses belajar mengajar lebih terarah. Sehingga, guru bisa memengaruhi siswanya untuk menumbuhkan minatnya dalam mengikuti pembelajaran suatu mata pelajaran, khususnya matematika. Hal itu sesuai dengan konsepsi pendidikan sebagaimana tertulis pada undang-undang No. 20 Tahun 2003 tentang Sistem Pendidikan Nasional pasal 1 ayat 1 yang berisikan bahwa Pendidikan merupakan upaya dalam menciptakan suasana dan kegiatan belajar agar siswa dapat mengembangkan kemampuan yang ada dalam dirinya untuk memiliki kepribadian, akhlak mulia, kecerdasan, serta keterampilan yang dibutuhkannya, masayakat dan juga negara.

Penyelenggaran pendidikan sendiri menurut Undang-Undang Nomor 20 Tahun 2003 tentang Sistem Pendidikan Nasional bertujuan agar dapat memberikan sumbagan yang positif sehingga dapat mewujudkan terbentuknya manusia sebagai generasi penerus bangsa dan negara Indonesia yang cerdas, mempunyai kemampuan, sikap sosial yang baik, dan dapat bergaul di masyarakat.

SD Unggulan Muslimat NU Kudus merupakan sekolah dasar swasta yang berdiri di atas lembaga sosial yaitu Muslimat NU Kudus sebagai upaya untuk memenuhi kelanjutan 


\section{Ummi Hanik Nashihah}

sekolah PAUD yang dipunyai oleh muslimat NU Kudus. Pendirian sekolah ini dirancang dengan menyesuaikan kebutuhan tempat dan zaman. Pewujudannya keunggulan mutu seklah diterapkan dengan adanya kegiatan kurikulum yang beragam dan terpadu. Kemampuan dasar dalam meguasai teknologi informasi dan bahasa asing sangat ditekankan sebagai jaminan pendidikan yang ada di sekolah tersebut, di sisi lain budaya lokal dan pelajaran agama juga diajarkan kepada peserta didiknya. Yang menarik adalah meskipun sekolah ini baru berusia 9 tahun, namun jumlah peserta didiknya sudah menyamai sekolah-sekolah dasar swasta unggulan dan favorit di kabupaten Kudus. Begitu pula dalam bidang prestasi, sekolah ini sudah mempunyai banyak prestasi yang diperoleh dalam jangka waktu kurang dari 9 tahun baik pada tingkat daerah maupuntingkat Nasional. Hal ini tidak lepas dari manajemen pendidikan yang dilaksanakan di SD Unggulan Muslimat NU Kudus, baik dari manajemen kurikulum, manajemen pembiayaan, manajemen sarana dan prasarana, manajemen pendidik dan tenanga pendidikan, hingga manajemen pembelajaran.

Berdasarkan hasil pendahuluan di SD Unggulan Muslimat NU Kabupaten Kudus melalui wawancara bersama Ibu Wihdal Muna Lukluaty selaku kepala sekolah bahwasanya manajemen pembelajaran diterapkan di SD Unggulan Muslimat NU Kudus untuk mencapai tujuan pendidikan tak terkecuali pada pembelajaran matematika. Pada pembelajaran matematika, kepala sekolah melaksanakan kebijakan bahwa mata pelajaran matematika dipisahkan dari buku tematik terpadu dan juga merekrut guru mata pelajaran (mapel) untuk membimbing siswa kelas atas yaitu dari kelas IV hingga kelas VI pada mata pelajaran matematika. Kebijakan ini dilaksanakan agar siswa mendapatkan pemahaman konsep matematika secara mendalam dan guru lebih fokus dalam merencanakan, melaksanakan, serta mengevaluasi pembelajaran matematika sehingga pembelajaran menjadi bermakna dan menyenagkan.

Guru mapel matematika di SD Unggulan Muslimat NU Kudus mempunyai cara jitu untuk menumbuhkan minat belajar siswa khususnya pada mata pelajaran matematika. Berdasarkan wawancara bersama Ibu Retno Tri Lidya Ningrum selaku guru mapel matematika, beliau memberikan apersepsi mengenai materi yang akan diajarkan dengan menghubungkannya dengan kehidupan sehari-hari agar siswa merasa tertarik untuk belajar. Selain itu guru tidak melulu menggunakan metode ceramah dalam proses pembelajaran, namun memberikan variasi dalam penggunaan metode pembelajaran misalnya dengan metode discovery (penemuan), diskusi, praktik, dan sebagainya. 


\section{Ummi Hanik Nashihah}

Penggunaan media juga diterapkan guru mapel dalam pelaksanaan pembelajaran sehingga menarik perhatian siswa untuk belajar. Hal-hal tersebut merupakan sebagian cara atau manajemen yang dilakukan guru dalam kegiatan pembelajaran matematika sebagai upaya meningkatkan minat belajar siswa agar tujuan pembelajaran matematika tercapai secara optimal.

Bertolak dari uraian diatas, penulis tertarik untuk mengetahui lebih dalam tentang manajemen pembelajaran matematika yang dilakukan dalam meningkatkan minat belajar siswa yang ada di SD Unggulan Muslimat NU Kudus. Permasalahan yang akan diteliti antara lain bagaimana minat belajar siswa, bagaimana perencanaan, pengorganisasian, pelaksanaan, dan evaluasi pembelajaran matematika di SD Unggulan Muslimat NU Kabupaten Kudus.

Jenis penelitian yang peneliti lakukan yaitu deskriptif kualitatif. Penelitian deskriptif kualitatif adalah pendekatan yang mengutamakan pengumpulan data atau kebenaran masalah dengan berasaskan pada penemuan informasi-informasi yang telah dilaksanakan dan diungkapkan oleh informan, serta data yang diperoleh dalam bentuk kata-kata dan bahasa oleh individu-individu dan perilaku yang diamati (Moleong, 2009: 3). Penelitian ini menggunakan pendekatan penelitian kualitatif dan tergolong ke dalam jenis penelitian lapangan (field research). Objek kajian penelitian ini adalah manajemen pembelajaran matematika dan minat belajar siswa. Adapun subjeknya terdiri dari kepala sekolah, guru mapel matematika, dan siswa. Penggalian data dilakukan pada tahun ajaran 2019/2020 dengan teknik wawancara, observasi, dan dokumentasi.

Pengecekan keabsahan data dilakukan dengan cara perpanjangan pengamatan, meningkatkan ketekunan dan triangulasi yang meliputi triangulasi sumber dan teknik. Sementara itu, data dianalisis dengan model analisis interaktif Miles dan Huberman yang dimulai dengan reduksi data, display data, hingga penarikan kesimpulan (conclusion drawing).

\section{B. Pembahasan}

Berdasarkan data yang didapatkan pada waktu penelitian, maka manajemen pembelajaran matematika dalam meningkatkan minat belajar siswa dapat disajikan sebagai berikut:

\section{Minat Belajar Siswa SD Unggulan Muslimat NU Kudus}

Minat merupakan kecenderungan seseorang untuk memberikan perhatian dan bertindak terhadap orang, aktivitas, atau situasi yang menjadi obyek dari minat tersebut 


\section{Ummi Hanik Nashihah}

dengan disertai perasaan senang. Minat yang dapat menunjang belajar adalah minat siswa kepada mata pelajaran dan kepada guru yang mengajarnya. Apabila siswa tidak berminat kepada mata pelajaran dan gurunya, maka siswa tidak akan mau belajar. Oleh karena itu, apabila siswa tidak berminat sebaiknya dibangkitkan sikap positif yaitu sikap menerima kepada pelajaran dan kepada gurunya, agar siswa mau belajar memperhatikan pelajaran. Minat belajar sangat penting dalam kegiatan pembelajaran, sebab minat merupakan salah satu faktor internal yang mempengaruhi pembelajaran. Minat akan tumbuh apabila siswa merasa tertarik akan pelajaran, karena sesuai dengan kebutuhannya dan bermanfaat bagi dirinya.

Dari hasil wawancara, observasi, dan observasi diperoleh data bahwa siswa-siswi SD Unggulan Muslimat NU Kudus memiliki minat belajar yang beragam pada mata pelajaran matematika. Oleh karena itu, diperlukan perasaan senang, perhatian, dan ketertarikan yang lebih terhadap mata pelajaran matematika untuk meningkatkan hasil belajar siswa. Siswa yang memiliki minat belajar terhadap mata pelajaran matematika, dapat membuatnya memiliki antusias dan kenyamanan dalam belajar sehingga dengan mudah siswa dapat berpikir kritis tentang matematika.

Agar matematika tidak menjadi momok menakutkan bagi peserta didik, banyak hal-hal yang perlu diperhatikan guru dalam pembelajaran, sebab guru memiliki andil yang cukup besar dalam meningkatkan minat belajar siswa. Pendekatan, metode dan media yang digunakan guru dalam pembelajan mempunyai pengaruh yang cukup signifikan untuk menarik siswa terhadap pelajaran matematika. Jadi, peran guru dalam merancang pembelajaran matematika semenarik mungkin juga dibutuhkan agar perlahan-lahan dapat menumbuhkan minat belajar siswa terhadap matematika. Oleh karena itu, dalam hal ini manajemen pembelajaran matematika yang menarik dapat dilakukan sebagai upaya untuk meningkatkan minat belajar siswa.

2. Perencanaan Pembelajaran Matematika dalam Meningkatkan Minat Belajar Siswa

Sekolah dasar sebagai lembaga formal dengan menerapkan konsep manajemen mulai dari perencanaan, pengorganisasian, pelaksanaan, dan evaluasi pembelajaran matematika diharapkan dapat berjalan efektif sehingga tercapai tujuan pembelajaran yang telah ditetapkan. Perencanaan pembelajaran merupakan dasar/acuan dalam melaksanakan kegiatan pembelajaran, sehingga perencanaan pembelajaran merupakan hal yang sangat penting dalam konteks kegiatan pembelajaran. Perencanaan yang dimaksud penulis dalam penelitian ini menekankan pada program rencana sekolah 


\section{Ummi Hanik Nashihah}

beserta guru matematika secara sistematis mengenai pengelolaan pembelajaran matematika. Perencanaan pembelajaran meliputi beberapa aspek yang berkaitan dengan persiapan pembelajaran.

Dalam aspek perencanaan pembelajaran, peneliti melakukan wawancara dengan Kepala sekolah, guru matematika, dan siswa SD Unggulan Muslimat NU Kudus. Pada pertanyaan yang pertama penulis menanyakan bagaimana perencanaan pembelajaran matematika yang dilakukan dalam meningkatkan minat belajar siswa.

Berdasarkan hasil wawancara, terungkap bahwa perencanaan pembelajaran matematika di sekolah ini harus dilakukan sebelum pelaksanaan pembelajaran dimulai. Hal tersebut diperoleh dari beberapa keterangan yang telah dipaparkan oleh beberapa narasumber yang mengatakan bahwa guru maupun pihak sekolah selalu melakukan perencanaan sebelum melaksanakan pembelajaran matematika di SD Unggulan Muslimat NU Kudus. Perencanaan yang dilakukan meliputi perumusan silabus, program tahunan, program semester, dan juga rencana pelaksanaan pembelajaran atau yang sering disebut RPP.

Adapun secara rinci komponen yang harus ada dalam rancangan RPP berdasarkan hasil wawancara, observasi, dan dokumentasi yang diperoleh di SD Unggulan Muslimat NU Kudus adalah sebagai beikut:

a. Tujuan pembelajaran

Tujuan merupakan komponen utama yang sangat harus ada dalam sistem pembelajaran. Akan dibawa kemana siswa, dan apa yang harus dilakukan oleh siswa semuanya tergantung pada tujuan yang ingin dicapai. Hal ini sesuai dengan prinsip pembelajaran yang berpusat pada guru yaitu kegiatan pembelajaran harus berorientasi pada tujuan.

Berpedoman pada tujuan pembelajaran maka apa yang telah disampaikan guruguru matematika dalam menentukan tujuan pembelajaran matematika adalah untuk memberikan target awal yang akan dicapai setelah proses pembelajaran berakhir. Dengan adanya penetapan tujuan pembelajaran ini diharapkan siswa mengetahui apa yang hendak dicapai, sehingga guru dapat memberikan semangat dan menumbuhkan minat belajar matematika kepada siswanya.

b. Materi pembelajaran

Pada dasarnya materi pembelajaran merupakan isi dari suatu kurikulum, yakni berupa mata pelajaran atau bidang studi dengan topik, sub topik dan rincian 


\section{Ummi Hanik Nashihah}

penjelasannya. Isi dari pelaksanaan pembelajaran tercermin dalam materi pembelajaran yang disapaikan kepada siswa. Syaiful Bahri Djamarah menjelaskan bahwa materi pembelajaran adalah substansi yang akan disampaikan dalam pelaksanaan pembelajaran. Tanpa materi pembelajaran, pelaksanaan pembelajaran tidak akan berjalan dengan baik (Djamarah, 2006: 43).

Guru hendaknya memperhatikan kriteria-kriteria dalam pemilihan materi pembelajaran, diantaranya yaitu materi harus sesuai tujuan pembelajaran, materi pembelajaran harus dijabarkan, materi sesuai dengan kebutuhan siswa, materi tersusun secara sistematis, dan materi hendaknya bersumber dari buku yang baku.

c. Media pembelajaran

Media pembelajaran merupakan peralatan atau benda yang membawa pesanpesan dalam upaya tercapainya tujuan pembelajaran. Media pembelajaran sangat beragam jenisnya, dan memiliki kelebihan dan kekurangannya masing-masing. Oleh karena itu, guru hendaknya dapat memilih media yang sesuai dengan kebutuhan pembelajaran, sehingga pelaksanaan pembelajaran dapat berjalan secara efektif dan juga efisien. Dalam pembelajaran, guru juga harus dapat memperlihatkan penggunaan media kepada siswanya dan menggunakannya secara maksimal.

d. Metode pembelajaran

Metode pembelajaran merupakan urutan, prosedur, langkah-langkah, dan juga cara yang digunakan guru untuk mencapai tujuan pembelajaran yang telah ditetapkan sebelumnya (Kusnadi, 2016: 13). Ketepatan pemilihan metode pembelajaran yang digunakan guru memungkinkan siswa untuk mencapai tujuan belajar secara efektif baik dari segi kognitif, afektif, maupun psikomotor. Penggunaan metode pembelajaran yang digunakan tepat, dapat dilakukan guru dengan memperhatikan beberapa faktor, yaitu tujuan pembelajaran, materi pembelajaran, kondisi siswa, kemampuan guru, sumber dan fasilitas, situasi, kondisi dan waktu. Penggunaan metode pembelajaran dengan memperhatikan beberapa faktor tersebut diharapkan kegiatan pembelajaran dapat berjalan dengan baik dan yang terpenting dapat menumbuhkan minat siswa untuk belajar.

e. Sumber belajar

Sumber belajar merupakan alat yang berkaitan dengan segala sesuatu yang memungkinkan siswa dapat memperoleh pengalaman belajar yang dapat mempermudah siswa dalam belajar. Sumber belajar ini bisa meliputi lingkungan 


\section{Ummi Hanik Nashihah}

fisik, seperti tempat belajar, bahan dan alat yang dapat digunakan, personal seperti guru, petugas perpustakaan dan ahli media, dan siapa saja yang berpengaruh baik langsung maupun tidak lansung untuk keberhasilan pembelajaran (Prastowo, 2018: 23). Dalam kegiatan pemebelajaran sumber belajar harus direncanakan dengan baik, guru harus melakukan perencanaan kegiatan yang akan dilakukan guru dan siswa dalam memanfaatkan sumber belajar secara optimal.

f. Evaluasi atau penilaian pembelajaran

Evaluasi atau penilaian digunakan untuk menentukan apakah tujuan pembelajaran dapat tercapai atau tidak. Evaluasi mempunyai tujuan untuk mengetahui tingkat kemampuan siswa, perkembangan masing-masing siswa, untuk mengetahui kekurangan dan kelemahannya, dan untuk mengetahui apakah pembelajaran yang dilaksanakan guru dapat berjalan dengan sukses atau tidak. Oleh karena itu evaluasi perlu direncanakan secara rinci sebelum pembelajaran dilaksanakan. Tahap perencanaan evaluasi ini meliputi penentuan tujuan evaluasi, menentukan alat evaluasi, dan menyusun instrumen evaluasi.

Dari hasil wawancara yang diperkuat juga dengan hasil pengamatan dan dokumentasi peneliti menyimpulkan bahwa perencanaan pembelajaran yang dilakukan guru matematika di SD Unggulan Muslimat NU sudah cukup dan menyeluruh. Perencanaan tersebeut meliputi penyusunan Silabus, program tahunan, prgram semesteran, RPP dan seluruh komponennya secara rinci.

3. Pengorganisasian Pembelajaran Matematika dalam Meningkatkan Minat Belajar Siswa

Pengorganisasian pembelajaran memiliki peran yang penting dalam kegiatan belajar mengajar khususnya dalam menyusun skema dan alur kegiatan pembelajaran. Pengembangan organisasi melalui visi dan misi tidak terbatas membentuk strategi, melainkan bagaimana kita harus dapat memadukan sebuah keterampilan mengelola strategi pengorganisasian pembelajaaraan yang terpadu. Terdapat beberapa faktor yang mempengaruhi perwujudan pengorganisasian pembelajaran diantaranya yaitu:

a. Kurikulum

Pengorganisasian kurikulum merupakan bentuk penyusunan bahan ajar atau pelajaran yang akan disampaikan dan diajarkan kepada siswa dengan tujuan agar mempermudah siswa dalam mengikuti kegiatan pembelajaran dan memahami bahan pembelajaran sehingga tujuan pembelajaran dapat tercapai secara optimal. 


\section{Ummi Hanik Nashihah}

Kurikulum kaitannya dengan pengorganisasian pembelajaran haruslah di rancang dan diselenggarakan secara terencana dan terarah serta terorganisir sebagai tanggung jawab sekolah dalam membantu anak-anak untuk mencapai tujuan pendidikannya. Sebab kegiatan pembelajaran bukan hanya dipusatkan pada penyampaian sejumlah materi pelajaran atau pengetahuan yang bersifat intelektual saja, tetapi juga harus memperhatikan aspek pembentuk kepribadian, baik sebagai makhluk individual dan makhluk sosial maupun sebagai makhluk yang bermoral.

Kurikulum yang diterapkan di SD Unggulan Muslimat NU Kudus pada tahun pelajaran 2019/2020 adalah kurikulum 2006 atau KTSP dan kurikulum 2013. Hal ini dikarenakan SD tersebut merupakan sekolah terakhir yang menggunakan kurikulum 2013. Untuk tahun selanjutnya direncanakan untuk menggunakan kurikulum 2013 untuk seluruh kelas yang ada di SD Unggulan Muslimat NU Kudus.

b. Guru

Guru sebagai pemeran utama dalam pelaksanaan program pembelajaran di sekolah memiliki peran yang sangat penting dalam mencapai tujuan pembelajaran yang diharapkan. Dalam proses pembelajaran, guru mempunyai tugas untuk memotivasi, mendidik, dan membimbing siswa untuk mencapai tujuan pembelajaran. Guru mempunyai tanggung jawab untuk melihat dan melibatkan segala sesuatu yang terjadi dalam pembelajaran untuk membantu proses perkembangan siswanya.

Dari hasil wawancara diperoleh bahwa pengelompokan guru dilakukan kepala sekolah SD Unggulan Muslimat NU Kudus untuk menunjang pembelajaran, khususnya dalam meningkatkan minat belajar matematika. Diantaranya yaitu adanya kebijakan mengenai pengadaan guru mata pelajaran matematika untuk kelas atas yaitu kelas IV, V, dan VI.

c. Siswa

Pengelompokan siswa biasanya didasarkan pada pandangan bahwa setiap siswa memiliki kesamaan dan juga perbedaan. Kesamaan yang dimiliki siswa memunculkan pandangan untuk menempatkan pada kelompok yang sama, sementara perbedaan siswa memunculkan pandangan untuk mengelompokkan mereka pada kelompok yang berbeda pula. Pengelompokkan siswa juga didasarkan atas pemikiran bahwa setiap siswa terus mengalami pertumbuhan dan perkembangan. Setiap siswa tumbuh dan berkembang sesuai kecepatannya masing-masing. Oleh karena itu, agar 


\section{Ummi Hanik Nashihah}

perkembangan siswa yang lebih cepat tidak mengganggu peserta dikit yang sedikit lambat atau sebaliknya, maka dilakukanlah pengelompokan siswa.

Seperti yang sudah ada di SD Unggulan Muslimat NU Kudus, siswa dikelompokkan berdasarkan kriteria-kriteria tertentu tergantung tujuan pendidikan ataupun tujuan pembelajaran yang telah dirumuskan. Untuk pembagian kelas, siswa dikelompokkan berdasarkan rangking yang diperoleh siswa. Adapun pengelompokan siswa dalam pembelajaran diserahkan sepenuhnya kepada guru, baik guru kelas maupun guru mata pelajaran. Hal ini dilakukan untuk membantu siswa agar berkembang seoptimal mungkin.

4. Pelaksanaan Pembelajaran Matematika dalam Meningkatkan Minat Belajar Siswa

Setelah kegiatan perencanaan dan pengorganisasian pembelajaran, langkah manajemen pembelajaran yang dilakukan adalah pelaksanaan pembelajaran. Seluruh kegiatan dalam pelaksanaan pembelajaran ini sudah direncanakan dalam rancangan RPP. Jadi pelaksanaan pembelajaran ini merupakan bentuk implementasi dari perencanaan pembelajaran yang telah dirumuskan sebelumnya.

Dalam pelaksanaan pembelajaran dibutuhkan prinsip, teknik dan tahapan yang optimal. Pelaksanaan pembelajaran yaitu mengarahkan semua personal agar ikut bekerjasama dan bekerja efektif dalam mencapai tujuan pembelajaran. Menurut kepala SD Unggulan Muslimat NU Kudus, beliau menjelaskan bahwa dalam konteks pembelajaran disekolah, tugas menggerakan dilakukan oleh kepala sekolah sebagai pimpinan instruksional, sedangkan dalam konteks kelas, penggerakan dilakukan oleh guru sebagai penanggung jawab pembelajaran. Penggerakan dalam kegiatan pembelajaran dilakukan oleh guru dengan suasana edukatif agar siswa dapat melaksanakan tugas belajar dengan penuh semangat sehingga mengoptimalkan kemampuannya dalam belajar dengan baik.

Berdasarkan hasil penelitian yang dilakukan peneliti saat pembelajaran matematika di SD Unggulan Muslimat NU Kudus diperoleh data bahwa terdapat tiga kegiatan yang dilakukan guru dalam pelaksanaan pembelajaran yaitu kegiatan pendahuluan, kegiatan inti dan kegiatan penutup. Kegiatan pendahuluan dimaksudkan utnuk mempersiapkan siswa dalam kondisi siap untuk mengikuti segala kegiatan dalam pembelajaran dan siap menerima pelajaran (Rukajat, 2018: 20). Pada kegiatan pendahuluan, diperoleh data bahwa terdapat beberapa usaha yang dilakukan guru matematika di SD Unggulan Muslimat NU Kudus, antara lain yaitu: 


\section{Ummi Hanik Nashihah}

a. Menyampaikan tujuan pembelajaran yang akan dicapai.

b. Menghubungkan materi yang akan disampaikan dengan materi yang telah dipelajari.

c. Menumbuhkan minat siswa dan memotivasi siswa.

d. Menjelaskan manfaaat dan pengaruh materi pelajaran matematika dalam kehidupan sehari-hari.

e. Melatih siswa kemampuan-kemampuan dasar matematika pada setiap jenjang kelas melalui kegiatan hafalan.

Setelah siswa dirasa siap mengikuti pembelajaran, maka tahapan selanjutnya adalah kegiatan inti. Kegiatan inti merupakan kegiatan yang paling utama dalam proses pembelajaran atau dalam proses penguasaan pengalaman belajar siswa. Kegiatan ini harus dilaksanakan secara sistematis dan sistemik melaluai kegiatan menanya, mengamati, mencoba, menalar, dan mengomunikasikan. Pada kegiatan inti, guru hendaknya menguasai tiga komponen berikut (Rukajat, 2018:21):

a. Guru mampu menguasai materi pembelajaran, sistematika penyampaian dan kejelasan konsep.

b. Guru mampu menggunakan pendekatan maupun metode pembelajaran yang sesuai dengan materi pembelajaran.

c. Guru mampu memilih dan memanfaatkan media pembelajaran yang tepat dan berkualitas sesuai dengan tujuan, materi, dan kemampuan siswa.

Ketiga komponen tersebut merupakan kemampuan-kemampuan dasar yang harus dimiliki oleh guru dalam pembelajaran sehingga tercipta iklim pembelajaran yang kondusif dan juga partisipatif serta dapat dikendalikan jika terjadi gangguan saat kegiatan pembelajaran.

Kegiatan terakhir dalam pembelajaran yaitu kegiatan penutup, kegiatan penutup ini bertujuan untuk memberikan gambaran secara menyeluruh tentang apa saja yang telah dipelajari siswa, mengetahui capaian belajar siswa, dan tingkat kemapuan guru dalam kegiatan pembelajaran (Rukajat, 2018: 21). Adapun upaya yang dilakukan guru dalam kegiatan penutup adalah sebagai berikut:

a. Merangkum pembelajaran yang telah dipelajari.

b. Mengkompromikan perhatian siswa terhadap materi yang telah diterima untuk membangkitkan minat dan kemmapuannya terhadap materi atau pelajaran selanjutnya.

c. Memberikan tindak lanjut berupa evaluasi. 


\section{Ummi Hanik Nashihah}

d. Memberikan saran serta ajakan untuk mempelajari kembali apa yang telah dipelajari dan yang akan dipelajari pada pertemuan selanjutnya.

5. Evaluasi Pembelajaran Matematika dalam Meningkatkan Minat Belajar Siswa

Evalusi pembelajaran merupakan proses pengukuran terhadap pertumbuhan, kemajuan dan perkembangan peserta didik dalam rangka mencapai tujuan pembelajaran yang telah ditetapkan (Arifin, 2011: 6). Kegiatan pembelajaran dikatakan berjalan efektif atau tidak dapat diketahui melalui kegiatan evaluasi. Evaluasi ini penting dilakukan secara benar karena bertujuan untuk mengetahui apakah tujuan pembelajaran yang telah ditetapkan dapat terlaksana sesuai dengan rencana yang telah ditetapkan atau tidak. Guru perlu menetapkan jenis evaluasi apa yang digunakan dan hasil evalusi tersebut diharapkan dapat berpengaruh dan berdampak terhadap perbaikan dan peningkatan mutu pembelajaran selanjutnya.

Evaluasi dalam suatu pembelajaran mempunyai peran yang sangat penting, sebab evaluasi dapat digunakan untuk mengetahui hasil belajar siswa selama mereka belajar, dengan demikian guru dapat mengetahuai nilai yang diperoleh siswanya, untuk membandingkan dengan siswa yang lainnya dan untuk melihat perkembangan atau kemajuan dari masing-masing siswa. Hasil yang diperoleh dari kegiatan evaluasi adalah kualitas dari pada sesuatu, baik yang menyangkut tentang nilai maupun arti. Sedangkan kegiatan untuk sampai kepada pemberian nilai dan arti itu adalah evaluasi. Sedangkan yang dimaksud dalam penulisan ini adalah evaluasi pembelajaran matematika yaitu suatu kegiatan untuk menaksir taraf kemajuan suatu pekerjaan di dalam pembelajaran matematika.

Evaluasi pembelajaran matematika dilaksanakan agar guru dapat mengetahui keberhasilan pencapian tujuan pembelajaran matematika setelah kegiatan pembelajaran selesai. Selain itu, melalui evaluasi pembelajaran dapat diukur mengenai keberhasilan guru dalam menyampaikan bahan pembelajaran. Dengan evaluasi pembelajaran guru diharapkan mampu menganalisa hal-hal apa saja yang harus diperbaiki dalam pelaksanaan pembelajaran berikutya sebagai upaya untuk meningkatkan kualitas pembelajaran di dalam kelas. Seperti bagaimana seharusnya menyampaikan materi dengan benar dan tepat agar siswa dapat mudah memahami dan menyerap apa yang disampaikan guru, metode apa yang seharusnya digunakan secara tepat, dan media seperti apa yang dapat membantu mempermudah proses pembelajaran. 


\section{Ummi Hanik Nashihah}

Fungsi evaluasi pembelajaran secara keseluruhan adalah sebagai berikut (Purwanto, 2004: 7):

a. Mengetahui perkembangan atau kemajuan kemampuan belajar siswa. Hasil dari evaluasi dapat digunakan untuk memperbaiki cara belajar siswa.

b. Mengetahui status akademis masing-masing siswa dalam kelasnya.

c. Mengetahui penguasaan, kelebihan dalam kekurangab seseorang siswa pada suatu unit pelajaran.

d. Mengetahui efisiensi metode dan media yang digunakan guru saat mengajar.

e. Menunjang pelaksanaan bimbingan konseling di sekolah. Yaitu untuk memberi laporan baik kepada siswa maupun orang tua.

f. Hasil evaluasi dapat digunakan untuk keperluan promosi siswa.

g. Hasil evaluasi dapat digunakan untuk perencanaan pendidikan selanjutnya.

h. Memberikan informasi kepada masyarakat yang memerlukan.

i. Merupakan feedback bagi siswa, guru dan program pengajaran.

j. Sebagai alat untuk memotivasi siswa untuk belajar dan guru dalam mengajar.

k. Hasil evaluasi dapat digunakan untuk keperluan perbaikan dan pengembangan kurikulum sekolah yang bersangkutan.

Evaluasi dalam pembelajaran juga berfungsi sebagai alat diagnosis belajar siswa, yaitu untuk mengetahui kesulitan ataupun hambatan yang dialami siswa selama mengikuti kegiatan pembelajaran. Dari hasil diagnosis tersebut dapat dijadikan dasar upaya tindak lanjut seperti bimbingan, perbaikan atau remedial. Dalam mengembangkan instrumen evaluasi pembelajaran, guru harus memperhatikan prinsip objektivitas, validitas, dan relibilitas. Adapun seccara khusus dan praktis dalam mengembangkan alat evaluasi pembelajaran, guru hendaknya memperhatikan beberapa kriteria berikut (Sukirman, 2012: 189):

a. Evaluasi harus berorientasi pada tujuan pembelajaran.

b. Evaluasi harus berdasarkan pada pengembangan kegiatan pembelajaran

c. Evaluasi harus memperhatikan waktu yang tersedia.

d. Evaluasi harus memungkinkan ada kegiatan tindak lanjut.

e. Evaluasi harus memberikan umpan balik.

f. Evaluasi harus berdasarkan pada bahasan materi.

Gambaran kualitas suatu pembelajaran dapat dilihat selama proses evaluasi yang dilakukan. Proses tersebut tentu dilakukan secara sistematis dan berkelanjutan, dalam 


\section{Ummi Hanik Nashihah}

arti terencana, sesuai dengan prosedur dan aturan, dan terus menerus. Kegiatan Evaluasi merupakan alat penilaian bagi guru untuk mengetahui keberhasilan pencapaian tujuan setelah proses pembelajaran berlangsung. Selain itu evaluasi adalah alat ukur untuk mengukur keberhasilan guru itu sendiri dalam menyajikan bahan pelajaran. Berdasarkan hasil data tentang evaluasi saat pembelajaran berlangsung, pada saat itu dapat dilihat bagaimana reaksi siswa, sikap siswa, kecepatan dan kelambatan setiap siswa. Apabila ditemukan siswa yang lambat dibandingkan dengan siswa lainnya maka guru membimbing kembali atau menyederhanakan materi pelajaran.

Berdasarkan hasil penelitian, bahwa teknik evaluasi yang digunakan oleh guru matematika di SD Unggulan Muslimat NU Kudus menggunakan teknik penilaian Formatif dan Sumatif. Penilaian formatif difungsikan untuk memantau dan penilaian sumatif difungsikan untuk melihat sejauhmana peserta didik itu dapat mengikuti suatu proses pembelajaran dan mencapai tujuan pembelajaran yang telah ditetapkan dalam rangka waktu tertentu (Arifin, 2011: 35). Kegiatan pembelajaran dan evaluasi juga mengacu pada seluruh domain hasil belajar, yaitu ranah kognitif (pengetahuan dan intelektual), ranah afektif (sikap), dan ranah psikomotorik (keterampilan). Hal tersebut dievaluasi secara kinerja, tulis, lisan, portofolio maupun observasi. Dengan demikian kegiatan evaluasi disini dimaksudkan menentukan apakah kemampuan siswa telah sesuai dengan tujuan yang telah ditetapkan sebelumnya atau belum.

Penggunaan teknik evaluasi juga harus berpedoman pada indikator pencapaian sesuai silabus materi yang telah dibuat sebelumnya. Dengan adanya indikator-indikator tersebut guru dapat merumuskan soal baik lisan maupun tulisan secara sistematis dan tetap terarah sesuai dengan indikator yang ada (Arifin, 2011: 91). Jadi, antara perencanaan, pelaksanaan dan mengelola data adalah satu kesatuan yang tidak dapat dipisahkan. Komponen tersebut menjadi satu kesatuan yang saling terkait dan saling mempengaruhi. Sehingga dalam meningkatkan kualitas pembelajaran matematika guru sebagai pelaku utama harus mampu menguasai ketiga komponen dasar tersebut.

\section{Simpulan}

Siswa-siswi di SD Unggulan Muslimat NU Kudus memiliki minat belajar matematika yang beragam. Diperlukan perasaan senang, perhatian, dan ketertarikan yang lebih terhadap mata pelajaran matematika untuk meningkatkan hasil belajar siswa. Peran guru dalam membangkitkan sikap positif dan merancang pembelajaran matematika dibutuhkan agar perlahan-lahan dapat menumbuhkan minat belajar siswa terhadap matematika. Oleh karena itu, dalam hal ini 


\section{Ummi Hanik Nashihah}

manajemen pembelajaran matematika yang menarik dapat dilakukan sebagai upaya untuk meningkatkan minat belajar siswa.

Manajemen pembelajaran dalam meningkatkan minat belajar pada mata pelajaran matematika dapat dilakukan melalui tahap perencanaan, pengorganisasian, pelaksanaan, dan evaluasi pembelajaran. Perencanaan pembelajaran matematika dilaksanakan sebelum kegiatan pembelajaran. Kegiatan yang dilakukan guru matematika dalam perencanaan pembelajaran secara umum adalah menyusun program Tahunan, Program Semesteran, Kalender Akademik, Silabus dan Rencana Pelaksanaan Pembelajaran (RPP). Untuk meningkatkan minat belajar siswa guru lebih mengoptimalkan dalam merencanakan komponen-komponen yang ada dalam RPP yaitu tujuan pembelajaran, materi pembelajaran, metode pembelajaran, media pembelajaran, sumber belajar, dan penilaian pembelajaran. Adapun pengorganisasian yang dilakukan dalam menunjang kegiatan belajar matematika diantaranya yaitu pengorganisasian kurikulum, sarana dan prasarana, guru, serta pengorganisasian siswa.

Pelaksanaan pembelajaran dilakukan dalam tiga kegiatan yaitu kegiatan pendahuluan, inti, dan penutup. Kegiatan-kegiatan tersebut disesuaikan dengan perencanaan pembelajaran yang telah disusun sebelumnya baik dari metode, materi, media, sumber belajar, maupun penilaian pembelajaran yang digunakan dalam pelaksanaan pembelajaran. Adapun evaluasi pembelajaran dilaksanakan dengan jenis evaluasi formatif dan sumatif. Kegiatan evaluasi mengacu pada domain belajar meliputi ranah kognitif, afektif, dan psikomotorik serta dievaluasi secara kinerja, tulis, lisan, portofolio maupun observasi .

\section{Daftar Pustaka}

Alquran dan Terjemahnya Al-Jumanatul 'Ali. 2005. Jakarta: Departemen Agama RI, CV Penerbit J-Art

Arifin, Zaenal. 2011.Evaluasi Pembelajaran, Bandung: PT. Remaja Rosdakarya

Bafadal, Ibrahim. 2004 .Manajemen Perlengkapan Sekolah Teori dan Aplikasinya, Jakarta: Bumi Aksara

Djamarah, Syaiful Bahri. 2006. Strategi Belajar Mengajar, Jakarta: PT Rineka Cipta

Gradini, Ega dkk. 2020. Evektivitas Penerapan Pembelajaran Matematika Qur'ani dalam Pembelajaran Himpunan, Al-Khawarizmi: Jurnal Pendidikan dan Pembelajaran Matematika, Vol. I, No. 1: 1-20.

Kusnadi, 2016. Metode Pembelajran Kolaboratif: Penggunaan Tools SPSS dan Video Scribe, Tasikmalaya: Edu Publisher

Lasmanawati, Ati. Opini : Meningkatkan Minat Belajar Matematika Siswa, Bangka Pos, $\begin{array}{lllll}\text { Senin } & (20 / 01 / 14) \quad \text { Diakses tanggal } 3 \text { Februari }\end{array}$ https:/bangka.tribunnews.com/2014/01/20/opini-meningkatkan-minat-siswa-belajarmatematika 
Moleong, Lexy J. 2009. Metodologi Penelitian Kualitatif. Bandung: PT Remaja Rosdakarya Mulyasa, E. 2010. Kurikulum Berbasis Kompetensi, Konsep, Karakteristik, Implementasi dan Inovasi. Bandung: PT Remaja Rosda Karya

Prastowo, Andi. 2018.. Sumber Belajar \& Pusat Sumber Belajar Teori dan Aplikasinya di Sekolah/Madrasah. Depok: Prenada Media

Purwanto, M. Ngalim. 2004.. Prinsip-Prinsip dan Teknik Evaluasi Pengajaran. Bandung: PT. Remaja Rosdakarya

Puspawati, Patria. 2008. "Manajemen Pembelajaran Pengalaman Lapangan Bidang Studi Matematika Kelompok Besar Paket A Nusa Indah di Kecamatan Bandar, kabupaten Batang". TESIS, Universitas Negeri Semarang

Rukajat, Ajat. 2008.. Manajemen Pembelajaran. Yogyakarta: Deepublish

Ruseffendi. 1989. E. T. Dasar-dasar Matematika Modern dan Komputer. Bandung: Tarsito

Rusman. 2011. Belajar dan Pembelajaran Berbasis Komputer. Bandung: Alfabeta

Shaleh, Abdul Rahman dan Muhbib Abdul Wahab. 2004. Psikologi Suatu Pengantar dalam Perspektif Islam. Jakarta : Prenada Media

Sukirman, Dadang. 2012. Pembelajaran Micro Teaching. Jakarta: Direktorat Jenderal Pendidikan Islam Kementerian Agama RI

Susanto, Ahmad. 2015. Teori Belajar \& Pembelajaran di Sekolah Dasar. cet.3, Jakarta: Prenadamedia Group

Sutikno, Sobri. 2012. Manajemen Pendidikan: Langkah Praktis Mewujudkan Lembaga Pendidikan yang Unggul Tinjauan Umum dan Islam. Lombok: Holistica

Wandini, Rora Rizki dan Oda Kinata Banurea. 2019.Pembelajaran Matematika untuk Calon Guru MI/SD. Medan: CV Widya Puspita 